\title{
Radna nedjelja u Hrvatskoj iz perspektive svetopisamskoga sedmoga dana
}

\author{
Arkadiusz KRASICKI* - Elvis RAŽOV** \\ • https://doi.org/10.31823/d.29.3.6 • \\ UDK: 27-23-42:331.31(497.5) • Pregledni članak \\ Primljeno: 11. prosinca 2020. Prihvaćeno: 24. rujna 2021.
}

${ }^{*}$ Doc. dr. sc.

Arkadiusz Krasicki, Teološko-katehetski odjel, Sveučilište u Zadru, Ulica dr. Franje Tuđmana 24i, 23000 Zadar, Hrvatska, akrasicki@unizd.hr

** Doc. dr. sc. Elvis Ražov, Teološko-katehetski odjel, Sveučilište u Zadru, Ulica dr. Franje Tuđmana 24i, 23000 Zadar, Hrvatska, erazov@unizd.hr

Sažetak: U radu se istražuju razlozi zbog kojih u Hrvatskoj nakon demokratskih promjena, unatoč mnogim aktivnostima udruga civilnoga društva i same Crkve, nema neradne nedjelje $z a$ one djelatnosti koje nisu nužne za održavanje redovitoga života društva i države. Analizom biblijskih tekstova koji govore $o$ »šabatu ili o sedmom danu te usporedivanjem iskustva izlaska izraelskoga naroda iz egipatskoga sužanjstva, jer Bog zahtijeva prinošenje žrtve u slobodi, s naporima današnjih vjernika u Hrvatskoj da nedjelju proslave neradno i u slobodi pokazuje se iz vjernicke perspektive razlika izmedu biblijske matrice i sadašnjih neuspješnih pokušaja. Naime u Bibliji je jasan naglasak na pravu i dužnosti vjernika da prvotno iska$\check{z} u$ slavu Bogu, iz čega proizlazi sloboda i odmor, dok se u današnjim pokušajima više naglašava, ne ispuštajući prethodno, pravo na odmor, obiteljsko zajedništvo i sl.

Ključne riječi: nedjelja, neradna nedjelja, šabat, štovanje Boga, sloboda, odmor.

\section{Uvod}

Nedjelja kao dan Gospodnji poziva na slavljenje Boga koji zahtijeva nedjelovanje, a daruje slobodu i odmor. Činjenica je da u suvremenoj Hrvatskoj, unatoč zakonskom pravu na odmor, to se pravo sve više krši, a osobito se ne konzumira u nedjelju u onim djelatnostima čiji rad nije nužan za život zajednice. U radu se stoga utvrđuje razlika između prakse i zakonske norme u totalitarnom vremenu i u vrijeme demokratske Hrvatske. Postavlja se pitanje koji su razlozi za takvu praksu. 
Crkva i mnoge udruge civilnoga društva, koje su joj svjetonazorski bliske, učinile su mnoge napore kako bi se osigurala slobodna nedjelja za radnike u onim djelatnostima o kojima ne ovisi vitalno funkcioniranje društva, osobito rad u trgovinama u kojima su zaposlene mnoge žene i majke, zbog čega je napose ugrožen obiteljski život.

U radu će se stoga analizirati biblijsko poimanje $\gg$ šabata $<$ ili sedmoga dana u Knjizi Postanka i u cijelom Petoknjižju kao polazna točka razumijevanja odnosa stvaranja, rada i odmora u svezi s obvezom slavljenja Boga. Analiza iskustva izlaska izraelskoga naroda iz egipatskoga sužanjstva središnja je točka u kojoj se spoznaje odnos kulta, slobode i odmora te se uspoređuje s pokušajima ostvarenja slobodne nedjelje u suvremenoj Hrvatskoj.

Analiza tekstova Isusova uskrsnuća pokušat će dati sintezu potpunoga teološkoga značenja »šabata « i podrijetla prvoga dana u tjednu, gdje se odmor i slavljenje ostvaruju u osobi Uskrsloga kojega se susreće u bogoslužju nedjeljnoga dana.

\section{Zakonska norma o regulaciji rada}

Sadašnja zakonska regulativa u Republici Hrvatskoj u Zakonu o radu propisuje pravo radnika na tjedni odmor u neprekinutom trajanju od najmanje 24 sata kojim će se koristiti nedjeljom, te u dan koji nedjelji prethodi, odnosno iz nje slijedi. Ako to nije moguće, za svaki radni tjedan omogućit će mu se korištenje zamjenskim tjednim odmorom nakon provedenoga razdoblja na radu. Za prekovremeni, noćni, nedjeljni, blagdanski ili rad u otežanim uvjetima radnik ima pravo na povećanu plaću. ${ }^{1}$

Iz perspektive zakonske norme koja regulira pitanje radne ili neradne nedjelje, a koja je izraz društveno-političkih odnosa prema radu u jednoj zajednici, zanimljivo je usporediti odnos prema neradnoj nedjelji u suvremenoj Hrvatskoj u odnosu prema istom pitanju u vrijeme kada je Hrvatska bila u sastavu bivše jugoslavenske federacije pod vlašću komunističke partijske diktature.

U Zakonu o udruženom radu iz 1976. godine, u članku 189., stoji da radnici imaju pravo na odmor tijekom dana, odmor između dvaju radnih dana, tjedni odmor, godišnji odmor i druge odmore te da tjedni odmor mora trajati najmanje 24 sata neprekidno. Premda se u Zakonu ne spominje da bi se taj jednodnevni odmor u tjednu trebao odvijati u nedjelju, zaista je to bila nedjelja. ${ }^{2}$

\footnotetext{
${ }^{1}$ Usp. čl. 75. i 94. Zakona o radu (Narodne novine br. 93/14, 127/17, 98/19).

${ }^{2}$ Usp. čl. 189. Zakona o udruženom radu (»Službeni list SFRJ «, br. 53).
} 


\subsection{ODMOR BEZ BOGOSLUŽJA I BOGOSLUŽJE BEZ ODMORA}

Uspoređujući zakon iz vremena komunizma i zakonska rješenja od stjecanja hrvatske neovisnosti do najnovijih promjena koje su stupile na snagu početkom 2020. godine i njihovu primjenu u praksi, može se uočiti da smo, od praktične zabrane rada nedjeljom u vrijeme planske ekonomije, u tržišnoj ekonomiji demokratski uređene države došli do potpune slobode poslodavaca da svoje radnike obvezuje na rad i nedjeljom. Bitna razlika između dvaju sustava sastoji se u tome što je komunistički uvažavao pravo na odmor (koji je praktično bio nedjelja) bez društveno priznatoga prava na bogoslužje (premda je privatno pravo na bogoslužje načelno bilo ozakonjeno), a demokratski priznaje pravo na javno štovanje i odmor, ali ga u konzumističkoj kulturi sve manje poštuje i nema neku posebnu obvezu prema nedjelji kao danu za javno štovanje Boga. Naravno, ovdje ne tematiziramo zabranu rada nedjeljom u svim djelatnostima koje su nužne i potrebne za funkcioniranje društvene zajednice, nego samo na one nenužne, odnosno specifično na pitanje rada nedjeljom u trgovinama zbog toga što su se mnoge dosadašnje inicijative crkvenih udruga uglavnom usredotočile na osiguravanje slobodne nedjelje radnicima u trgovinama.

Zašto je tomu tako? Namjera nije ulaziti u ekonomske analize odnosa rada i kapitala, odnosno odnose radnika koji žele zaraditi plaću za dostojan život i poslodavaca koji žele maksimirati dobit, već u potrebu tjednoga odmora koji se upravo treba omogućiti u nedjelju koja je dan Gospodnji u kojem se i sam Gospodin odmorio od svoga djela stvaranja. Onima koji ne spore pravo radnika na odmor, ali smatraju da se za odmor može koristiti i nekim drugim danom u prilog ide i izjava iz Nacionalnoga stožera civilne zaštite da se u kontekstu koronakrize može smanjiti mobilnost radnika i neki drugi dan osim nedjelje. ${ }^{3}$ Praktično to znači priznanje mogućnosti odvajanja nedjelje kao dana Gospodnjega od dana odmora.

\subsection{INICIJATIVE ZA NERADNU NEDJELJU}

Početkom 21. stoljeća poduzete su mnoge akcije i formirani savezi radi zaštite slobodne nedjelje i u Europi i u Hrvatskoj. ${ }^{4}$ Prevladavajući razlozi tih inicijativa da se traži zaštita slobodne nedjelje nalaze se u zaštiti djece i žena od prekovremenoga rada, pravu na odmor, dobrobiti obitelji, opće dobrobiti društva u cjelini, zaštiti

\footnotetext{
${ }^{3}$ Usp. Capak: Može se ne raditi i neki drugi dan, to ne mora biti nedjelja, u: OTVORENO.hr. Dostupno na: https:/ / otvoreno.hr/vijesti/capak-moze-se-ne-raditi-i-neki-drugi-dan-to-ne-mora-biti-nedjelja/280551 (25. 4. 2020.).

${ }^{4}$ Usp. V. KANIĆ, Sloboda od rada nedjeljom kao pitanje radnog i socijalnog prava, u: G. ČRPIĆ, M. DŽOLAN (ur.), Slobodna nedjelja: kultura u nestajanju?, Zagreb, 2014., 137-138.; Usp. E. ŠEBA, Free Sunday Campaign. A Case Study from Croatia, u: Nova prisutnost 17(2019.)3, 579-595.
} 
temeljnih ljudskih prava i sl. Hrvatska biskupska konferencija, osobito Komisija Iustitia et pax, i druge crkvene i laičke udruge tražile su pravo na nedjeljni odmor i slobodno bogoštovlje za svoje vjernike, ali i za sve druge koji imaju pravo na odmor i slobodan dan u tjednu. Nažalost, sve te inicijative nisu u konačnici dovele do zadovoljavajućih rješenja u obliku zakonskih odredbi koje bi zajamčile neradnu nedjelju u okviru hrvatskoga zakonodavstva.

Postavlja se pitanje zašto te inicijative nisu urodile plodom. Je li razlog u nedovoljnom isticanju i inzistiranju na prvotnoj religioznoj dužnosti i pravu vjernika na štovanje Boga u nedjeljni dan? Je li razlog u nejasnoći odnosa i prioriteta između štovanja Boga i odmora? Je li razlog nejasnoća da sloboda uopće proizlazi iz religiozne slobode štovanja pravoga i jedinoga Boga te da su ugrozom te slobode ugrožene i sve druge slobode koje pripadaju čovjeku? Je li kompromis sa sekularističkom kulturom, koja ispražnjava odmor od njegovih religijskih motiva i zasada te blagdan pretvara u praznik, ${ }^{5}$ a religijske razloge uopće ne prihvaća kao valjane u zakonskom uređenju odnosa, oslabio mogućnost postizanja željenoga rezultata?

Gledajući na problem neradne nedjelje iz vjerničke perspektive te pobliže iz svjedočanstva biblijskoga poimanja šabata, nastojat ćemo potražiti jedan od mogućih razloga za neuspjeh u razumijevanju sedmoga dana u svetopisamskoj objavi Staroga i Novoga zavjeta te posebno u iskustvu izlaska izraelskoga naroda iz egipatskoga sužanjstva.

\section{Nedjelja - sedmi dan}

Riječ nedjelja ne postoji u Svetom pismu. No to ne znači da se o njoj ne može promišljati na temelju biblijskih tekstova. Prve stranice Biblije govore o posebnom danu $\gg$ počinka « ili $\gg n$ nedjelovanja $\ll$, što nas upućuje na nedjelju. U tom kontekstu nedjelja nije proizvoljna ljudska umotvorina, nego ona postaje od Boga određen dan u kojem ga se štuje, a i svaka druga radnja usmjerena je na slavljenje Boga u djelu stvaranja. Starozavjetne knjige dan Gospodnji nazivaju subota (šabat). Biblijsko određenje nedjelje puni je izraz božanske objavljene volje. Time je izrečen i odnos ljudskoga i božanskoga djelovanja koje je uređeno prema nedjelji te povezano sa stvaranjem.

\subsection{Dan počinka, SLAVljenja Boga I Slobode}

Opis stvaranja svijeta (Post $1,1-2,4)$ predstavlja Božji zahvat u povijest čovještva na mikrorazini i makrorazini. Sve što je Bog učinio na nebu i na zemlji bilo je

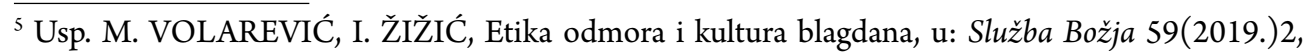
176-195., ovdje 177. 
$\gg$ dobro « koje odzvanja poput refrena iza svake kitice kojom biblijski pisac opjevava Božje djelo. U šestom danu Bog stvara čovjeka. Ovdje se nalazi usklik »vrlo dobro « (Post 1, 31). Čini se da je Bog oduševljen djelom stvaranja, ali ne u smislu prividne ljudske satisfakcije, nego svojim autoritetom potvrđuje kvalitetu stvaranja, harmoniju i najsavršenije dobro. Božji usklik koji nadahnuti autor stavlja u usta Boga Stvoritelja, čini se, omeđuje šest dana stvaranja i sedmi dan, koji se povezuje s Božjim »nedjelovanjem «, odnosno Božjim »otpočinkom «, iako je riječ o namjernom antropomorfizmu. »Tako bude dovršeno nebo i zemlja sa svom svojom vojskom. I sedmoga dana Bog dovrši svoje djelo koje učini. I počinu u sedmi dan od svega djela koje učini. I blagoslovi Bog sedmi dan i posveti, jer u taj dan počinu od svega djela svoga koje učini.« (Post 2, 1-2)

U izvještaju se ne spominje subota, nego tri puta sedmi dan. No treba naglasiti da je subota sadržana u izrazu »počinu «, što na hebrejskom znači šabat. Prema tomu taj dan jest dan prestanka Božjega rada. Gospodin blagoslovi i posveti taj dan. Time sedmi dan odjeljuje od drugih dana. ${ }^{6}$ Šabat znači počivati, odmarati se, ne raditi, ali uz to označava i blagoslivljanje i zahvaljivanje. Prema tomu dan Gospodnji (usp. Otk 1,10$)$ u sebi sadrži slavljenje Boga iz kojega izvire počinak. ${ }^{7}$ Cijelo stvorenje, čitav kozmos usmjeren je prema šabatu, u kojem ima udjela u Božjem mirovanju i njegovoj slobodi. Stoga je šabat vizija slobode u kojoj su i rob i gospodar izjednačeni. »Čovjek je slobodan i moguća je jednakost i dostojanstvo svih ljudi samo ako je taj isti čovjek u savezu s Bogom. $\ll^{8} \mathrm{Iz}$ toga je vidljiva jasna uzročno-posljedična veza posvećenoga dana Gospodinu koji ljude oslobađa uvodeći ih u Božji odmor. Tako dan otpočinka postaje blagdanom slobode. $\gg$ Blagdan je, dakle, određen vrednotom slobode ukorijenjenom u susretu s događajem stvaranja i otkupljenja. Obustava svagdanjega posla preduvjet je da se blagdan dogodi kao dan milosti i počinka, odnosno da on bude odmor duše i tijela. ${ }^{9}$

Kao što primjećuje B. Odobašić:

»U suboti se susreće vrijeme Božje i vrijeme čovjeka, Božjeg djela stvaranja i počinka s ljudskim radom i počinkom. Božja zapovijed o počinku u subotu ima uz teološku i socijalnu dimenziju. Čovjek treba počinuti u subotu i sjetiti se Božjih djela kojima štiti njegov život. Čovjek je od Boga blagoslovljen (Post 1,28) a subota je blagoslovljena i posvećena (Post $2,3)$. Subota je tim iznad čovjeka. Zato je i čovjek pozvan da se u subotu

\footnotetext{
${ }^{6}$ Usp. C. TOMIĆ, Prapovijest spasenja, Zagreb, 1977., 86.

${ }^{7}$ Usp. M. VOLAREVIĆ, I. ŽIŽIĆ, Etika odmora i kultura blagdana, 186-187.

${ }^{8}$ J. RATZINGER, Duh liturgije, Split, ${ }^{2} 2015$., 22-23.

${ }^{9}$ M. VOLAREVIĆ, I. ŽIŽIĆ, Etika odmora i kultura blagdana, 192.
} 
posvećuje. Izrael je posvećenjem subote odvojen za svoga Boga iz profanog svijeta. Izrael je odvojen i pozvan da slavljenjem subote sudjeluje u Božjem naumu posvećenja svijeta. $\ll^{10}$

Svaki je čovjek pozvan dati slavu Bogu na dan subotnji, odnosno na dan odmora. Šabat je potvrđen kao dan kulta i na Sinaju, gdje Bog upisuje Zakon u kamene ploče. Time sklapa s čovjekom savez.

\section{2. ŠABAT I SAVEZ}

Od samih početaka, od Mojsija, ali i prije njega, šabat je bio dan veselja, radosti: blagdan (Hoš 2, 13; Iz 58, 13). U Mojsijevo doba on je postao dan posvećen Gospodinu, dan odmora i molitve (Izl 34, 21; Am 8, 5). Bio je vezan uz savez koji je Bog sklopio s narodom. On je također spomen na Božji osloboditeljski zahvat kada je Bog oslobodio svoj narod od teškoga rada u Egiptu te ga je uveo u »Počivalište « (Pnz 12, 9; Ps 95, 11). ${ }^{11}$ Dan Pashe, dan izlaska iz Egipta - kuće ropstva, Sveto pismo otkriva kao dan Gospodnji, dan oslobođenja. ${ }^{12} \gg$ Sjeti se da si i ti bio rob u zemlji egipatskoj i da te odande izbavio Jahve, Bog tvoj, rukom jakom i ispruženom mišicom. Zato ti je zapovjedio Jahve, Bog tvoj, da držiš dan subotnji.«(Pnz 15, 5) Bog oslobađa Izraelce iz Egipta - kuće ropstva - kako bi ih pozvao na bogoslužje u pustinji. Tu će se oni klanjati Jedinom Bogu. Osim toga zapovijed o svetkovanju subote vraća također, u teološko-antropološkom smislu, na oslobođenje izabranoga naroda iz babilonskoga sužanjstva. Izraelci su, zahvaljujući blagdanu počinka, očuvali svoj identitet upravo slušanjem Božje riječi i liturgijskim slavljem. ${ }^{13}$ Tako su se Izraelci približavali Božjem obećanju izgovorenom još Abrahamu - obećanoj zemlji.

\subsection{ObeĆana zemlja kao mjesto štovanja Boga}

Zahtjev za izlaskom iz Egipta, koji Mojsije upućuje faraonu, u sebi sadrži dva različita motiva i razloga: obećana zemlja (sa svojim teritorijem, granicama, slobodom i neovisnošću) i štovanje Boga u pustinji. Posljednji se jasno očituje faraonu, a prethodni se, prema faraonovu mišljenju, tobože, skriva kao pravi razlog kojemu posljednji treba poslužiti kao trik. Faraon, čini se, misli da je taj razlog opravdanje za bijeg te ga nastoji spriječiti političkim pregovorima kojima bi se onemogućilo autentično bogoštovlje tako što predlaže štovanje Boga u zemlji ropstva. Kad to

${ }^{10}$ B. ODOBAŠIĆ, Savez na Sinaju - objava Božjeg milosrđa. Teologija Saveza u Knjizi Izlaska, u: Bogoslovska smotra 80(2010.)1, 167-197., ovdje 186.

${ }^{11}$ Usp. A. REBIĆ, Biblijske starine, Zagreb, 1992., 201.

${ }^{12}$ Usp. Katekizam Katoličke Crkve, Zagreb, 2016., br. 2170. (= KKC).

${ }^{13}$ Usp. L. TOMAŠEVIĆ, Teologija i moralnost nedjelje prema novijim dokumentima Crkve, u: Služba Božja 44(2004.)1, 86-98., ovdje 88. 
nije prihvaćeno, dopušta samo muškarcima odlazak u pustinju, a na kraju je popustio i dopustio odlazak ženama i djeci, ali ne i stoci. Mojsije ustraje na tome da bogoštovlje nije podvrgnuto političkim dogovorima, nego je određeno Božjom voljom iznesenom u Objavi. Bogoštovlje zahtjeva slobodu, i to za sve. Ne samo za muškarce, žene i djecu nego i za svu stoku koju Izrael posjeduje u Egiptu. Traži se izlazak u slobodu pustinje kako bi se iskazalo pravo bogoštovlje. Cilj rasprave između Mojsija i faraona nije obećana zemlja, nego pravo bogoštovlje u slobodi koju Bog osigurava kad ga čovjek štuje po Njegovoj uredbi. Stoga je sloboda posljedica zahtjeva za bogoslužjem, a pravo bogoslužje nije moguće bez slobode, oslobođene od političkoga kompromisa. ${ }^{14}$

Izrael je narod koji treba biti poseban po tome što on služi Bogu, na gori Božjoj u autentičnom bogoštovlju, u zemlji koju je Bog obećao Abrahamu. U tome vidimo suglasje između dvaju razloga izlaska iz Egipta, zemlje i bogoštovlja. Zemlja je darovana da bi bila mjesto štovanja pravoga Boga, a ne da bi se postigla samo puka nacionalna autonomija koja bi Izrael učinila jednakim svim drugima narodima. Bogoštovlje koje ima svoj vrhunac u sedmom danu daje okvir za nacionalni ustroj i pravni poredak izraelske države (Deset zapovijedi na Sinaju) koja ima svoj teritorij i granice. Kada Izrael bude zaboravio da je središte njegova života bogoštovlje, što se konkretno pokazuje u nepoštivanju šabata, gubit će zemlju i odlaziti u ropstvo dok se zemlja ne oduži svojim subotama. ${ }^{15}$ Održavanje šabata uvijek će se povezivati sa slobodom.

\section{4. ŠABAT DAN SLOBODE ZA SVE}

Pasha poprima dimenziju slobode u Bogu. $\gg U$ cijeloj toj raspri (između Mojsija i faraona) nije bit i cilj nekakva Obećana zemlja. Kao jedini cilj izlaska pojavljuje se bogoštovlje i poklon Bogu, koji će se izvršiti jedino prema Božjim mjerilima i zahtjevima, te je stoga izuzeto iz pravila političkog dogovora ili sporazuma između Mojsija i Arona s jedne i faraona s druge strane. $\ll^{16}$

Budući da je čovjek stvoren na Božju sliku (Post 1,27), pozvan je činiti ono što Bog čini. Božje djelovanje uzor je za ljudsko djelovanje. Ako je Bog sedmoga dana otpočinuo, i čovjek je pozvan na isto. Božji prestanak rada poziv je upućen čovjeku da i on na dan počinka prestane $s$ teškim radom. I čovjek mora odmoriti kako bi blagoslovio Božje djelo i njemu zahvaljivao. Osobni odmor upućen je također na drugoga, osobito siromaha, pa čak i roba (usp. Izl 31, 17).

\footnotetext{
${ }^{14}$ Usp. J. RATZINGER, Duh liturgije, 11-12.

${ }^{15}$ Usp. isto, 13-14.

${ }^{16}$ Isto, 12.
} 
Izraelci su se morali pripremiti za šabat - dan odmora - dok su išli kroz pustinju: $\gg$ On im reče: 'Ovo je zapovijed Jahvina: Sutra je dan potpunog odmora, subota Jahvi posvećena. Ispecite što želite peći; skuhajte što želite kuhati. Sve što vam preteče ostavite za sutra.'« (Izl 16, 23) Dan odmora bio je vrlo strogo određen prema svakom čovjeku: »A sedmoga je dana subota, počinak posvećen Jahvi, Bogu tvojemu. Tada nikakva posla nemoj raditi: ni ti, ni sin tvoj, ni kći tvoja, ni sluga tvoj, ni sluškinja tvoja, ni živina tvoja, niti došljak koji se nađe unutar tvojih vrata.« (Izl 20, 10) Subota, odnosno dan Gospodnji, dan odmora, zauvijek će biti znak vječnoga saveza koji je Bog sklopio s čovjekom. ${ }^{17}$

U Izraelu se šabat također povezuje s jubilarnom godinom. To je bila svaka sedma godina. Tada su otpuštali robove, puštali su tlo neobrađenim, nisu ubirali plodove maslina i vinove loze (Izl 23, 10-11). Dan odmora jest prema tomu dan slobode i dostojanstva svakoga čovjeka. On zahvaća također i područje prirode i zemlje. Sedmi dan, dan odmora, jest sveti zakon koji se zasniva na vječnoj božanskoj volji te ima svoj temelj u ljudskoj naravi. Prema tomu to nije ljudski zakon ili Mojsijeva naredba, nego Božji plan. To je objava. ${ }^{18}$

Ljudska narav traži povremeni prestanak rada, odmor koji poput zamašnoga kotača daje novi polet djelu usavršavanja mira. Rad iscrpljuje ako ga se ne isprepliće odmorom. U starini gospodari robova nisu dopuštali robovima pravi odmor. Oni su morali raditi bez prestanka. To je bila nepravda veća od samoga ropstva. ${ }^{19}$

Biblija, koja pokazuje Boga na djelu, predstavlja čovjekov život koji se uvijek povezuje s radom. Nažalost, moderno doba, sa svojom vjerom u napredak i znanost, $s$ pretjeranim pouzdanjem u moć stvaralaštva i tehnike, stvorilo je osjećaj da će religija nestati kad znanost odgovori na sve ljudske potrebe. Znanosti i tehnici obraća se na isti način na koji se jednoć obraćalo Bogu. ${ }^{20} \mathrm{U}$ tom kontekstu rad postaje čovjeku idol i zauzima mjesto Boga i njegove Objave.

Subota - dan počinka - obustavlja svakidašnji posao i omogućuje odmor. Ona postaje danom prosvjeda protiv robovanja radu. ${ }^{21}$ Svi komentatori odlomka o stvaranju slažu se da je sedmi dan, dan Gospodnji, dan slavljenja Boga koji želi susresti svoj narod. To je dan slobode i mira, blagoslova i blaženstva. To je dan u kojem čovjek mora osjetiti Božje prijateljstvo te razlikovati taj susret od ostalih poganskih

\footnotetext{
${ }^{17}$ Usp. KKC, br. 2171.

${ }^{18}$ Usp. C. TOMIĆ, Prapovijest spasenja, 87.

${ }^{19}$ Usp. isto, 86.

${ }^{20}$ M. VOLAREVIĆ, I. ŽIŽIĆ, Etika odmora i kultura blagdana, 176.

${ }^{21}$ Usp. KKC, br. 2172.
} 
načina slavljenja zbog neotkrivenoga čeznuća za Bogom. To je dan oslobođenja od kulta novca i rada.

\section{Novozavjetno poimanje sedmoga dana}

Starozavjetna poruka o važnosti sedmoga dana zadržava svoju aktualnost i snagu i u Novom zavjetu. Dan Gospodnji zauvijek je dan odmora, slavljenja Boga u kojem je čovjek pozvan na slobodu. S Kristovim dolaskom vrijeme dobiva novu dimenziju. Dan Gospodnji jest dan Kristov. ${ }^{22}$ To potvrđuje Ivan u Otk 1, 10 (dies dominica). On je tijekom dana Gospodnjega - tj. u nedjelju, imao viđenje neba i pozvan je bio »uzići na nebo « $(\mathrm{Otk} 4,1-2) .{ }^{23} \mathrm{U}$ središtu novozavjetne poruke jest slavljenje nedjelje kao prvoga dana u tjednu (usp. 1 Kor 16, 2; Dj 20,7). Na taj su dan prve kršćanske zajednice svetkovale Gospodina. Padao je na prvi dan poslije subote. Tim izborom nije se htjela istisnuti subota, nego slaviti spomen povijesnoga događaja Isusova uskrsnuća. ${ }^{24}$ Prema tomu dan Gospodnji ili prvi dan u tjednu ili dan odmora (šabat - po svom etimološkom značenju) poistovjećuje se s prvim danom nakon subote, odnosno s nedjeljom na spomen Isusova uskrsnuća (Mk 16, 2; Iv 20, 1.19). $\mathrm{Na}$ taj se dan prakršćanska zajednica okupljala na euharistiju (Dj 20, 7; 1 Kor 16, 2). ${ }^{25}$ Predaja će taj dan nazvati i osmim danom kako bi podsjetila na to da je na taj dan Uskrsa - u kojem se unaprijed ostvaruje parusija - stvorenje prvoga dana došlo do svoga punoga dovršenja. ${ }^{26}$ Novi zavjet osam puta spominje izraz $\gg$ prvi dan $u$ tjednu (Mt 28, 1; Mk 16, 2.9; Lk 24, 1; Iv 20, 1.19; Dj 20, 7; 1 Kor 16, 2) koji se poistovjećuje s nedjeljom. Isus svojim uskrsnućem otkriva pravi smisao šabata.

\subsection{IsUS I ŠABAT}

Evanđelja izvješćuju da je Isus u više navrata »kršio « šabat (Mk 2, 27-28; Mt 12, 8; Lk 6, 1-5). Prema mišljenju farizeja, Isus je kršio dan subotnji jer je dopustio svojim učenicima trgati klasje na dan šabata, što je bilo Zakonom zabranjeno. U perikopi iz Mk 2, 18-22 nalazimo starozavjetnu argumentaciju o Davidu i njegovim pratiocima kojima je hramski svećenik dopustio blagovanje posvećenih kruhova. Isus, pozivajući se na taj događaj, odgovara na njihovu zamku: »I govoraše im: 'Su-

\footnotetext{
${ }^{22}$ Usp. P. AUVRAY, X. LÉON-DUFOUR, Dan Gospodnji, u: X. LÉON-DUFOUR i dr. (ur.), Rječnik biblijske teologije, Zagreb, ${ }^{4}$ 1993., 173-185., ovdje 175.

${ }^{23}$ Usp. A. SZUSTAK, Straszna książka, Kraków, 2018., 253-259.

${ }^{24}$ Usp. P. AUVRAY, X. LÉON-DUFOUR, Dan Gospodnji, 181.

${ }^{25}$ Usp. P. VEIMAR, Nedjelja, u: A. GRABNER-HAIDER, Praktični biblijski leksikon, Zagreb, 1997. 236.

${ }^{26}$ Usp. P. AUVRAY, X. LÉON-DUFOUR, Dan Gospodnji, 181.
} 
bota je stvorena radi čovjeka, a ne čovjek radi subote. Tako, Sin Čovječji gospodar je subote!'«

Isus iznosi izvorno razumijevanje šabata koje nadilazi farizejsko shvaćanje propisa koji uređuju odnos prema sedmom danu, a koji su za Židove postali opterećenje (usp. Mt 23, 4). Čini se da su zaboravili da je subota nastala kao izraz Božje milostive brige za čovjeka. ${ }^{27}$ Isus donosi mnogo dublje načelo u kojem pokazuje da je smisao šabata da izdigne čovjeka iznad rutine tjednoga rada te da ispuni jedinstvenu privilegiju koju mu je Bog dao, tj. da živi u savezu s Bogom. ${ }^{28} \mathrm{U}$ suprotnome smisao šabata bio bi u opreci s Božjim naumom o stvaranju svijeta i čovjeka. Treba također na tom mjestu istaknuti Isusov autoritet po pitanju šabata u 2, 27 koji se povezuje s r. 28. Čovjek ne smije postat robom posla i novca s jedne strane, ali s druge strane ne smije postati ni robom šabata. ${ }^{29}$ Isusov navještaj da je On gospodar subote bio je za ljude onoga vremena zaprepašćujuća novost. ${ }^{30}$ Redak 28. upozorava na Isusov naslov Sin Čovječji, koji se na tom mjestu referira na »čovjeka «. Prema tomu on je taj čovjek radi kojega je stvoren šabat kao dan Gospodnji, kao dan slobode. Isus je čovjek - Novi Adam. ${ }^{31}$ S druge pak strane Isus je kao Sin Čovječji Gospodar subote. Time se referira na svoje božansko podrijetlo koje dopušta božanskim autoritetom tumačiti propise vezane uz dan odmora. ${ }^{32}$

U svojoj dobroti i mudrosti Isus subotom dopušta činiti dobro, a ne zlo, život spasiti, a ne pogubiti $(\mathrm{Mk} 3,4)$. Tema odnosa Isusa prema šabatu proteže se i na sljedeće poglavlje. Taj je put riječ o ozdravljenju čovjeka s usahlom rukom (Mk 3, 1-6). Isus se kroz temu šabata približava najavi svoga uskrsnuća. Čovjeku s usahlom rukom govori: »Stani na sredinu! « Grčki izraz egeiro, osim značenja 'stati, podignuti', označava također i 'ustati'. To je ista riječ koja se koristi u Markovoj kompoziciji 16, 6. Dakako, nitko ne može postati robom šabata po zakonu, a kamoli kršiti ga. Šabat je dan spasenja, zato je dopušteno »dobro činiti « na dan šabata. Farizejska su srca bila tvrdokorna. Stoga su odbacivali Isusov nauk čineći time zlo na dan šabata. ${ }^{33}$ Isus, Gospodar šabata, nudi oslobođenje, što istinski upućuje na bit šabata. Bolesnik je mogao vidjeti na sebi slavu Sina Čovječjega. Ozdravljenje čini čovjeka slobodnim, lišenim trpljenja. On postaje slobodno Božje dijete. Čovjek udaljen od

${ }^{27}$ Usp. A. R. COLE, Evanđelje po Marku, Daruvar, 1997., 84.

${ }^{28}$ Usp. M. HEALY, The Gospel of Mark, Michigan, 2008., 65.

${ }^{29}$ Usp. H. LANGKAMMER, Evangelia według św. Marka, Poznań - Warszawa, 1977., 120.

${ }^{30}$ Usp. K. ROMANIUK, Komentarz praktyczny do Nowego Testamentu, Poznań - Kraków, 1999., 180.

${ }^{31}$ Usp. D. J. HARRINGTON, Evanđelje po Marku, u: D. J. HARRINGTON i dr. (ur.) Komentar Evandelja i Djela apostolskih, Sarajevo, 1997., 37-127., ovdje 57.

${ }^{32}$ Usp. A. R. COLE, Evandelje po Marku, 84.

${ }^{33}$ Usp. M. HEALY, The Gospel of Mark, 67. 
Gospodara šabata nije slobodan. Takvo stanje uvlači ga u zarobljenost i smrt. ${ }^{34} \mathrm{Bu}-$ dući da je Isus Gospodar šabata, pravi se odmor može dogoditi samo u njemu.

\subsection{ODMOR U IsUSU}

Odlomak iz Matejeva evanđelja 11, 25-30 spada među najpoznatije Isusove govore. On objavljuje povezanost Oca i Sina, ali i uz usklik radosti poziva na sveti odmor povezan sa štovanjem Božje mudrosti. ${ }^{35}$ Stoga treba taj odlomak razumjeti u kontekstu starozavjetnoga poimanja odmora u odnosu Stvoritelj - Presveto Trojstvo ${ }^{36}$ te u relaciji čovjek - stvorenje (Post 1, 26 - 2, 4). Gledajući strukturu 11. i 12. poglavlja Matejeva evanđelja, može se lako primijetiti tematska povezanost perikopa 11, 25-30 i 12, 1-14 u kojima Isus govori o šabatu kao danu odmora posvećenom Bogu.

Prije svega, u Mt 11, 25-27 vidljiv je odnos intimne povezanosti Oca i Sina. Dakako, taj odlomak upućuje na povezanost starozavjetne i novozavjetne poruke o odmoru koji dolazi iz Božjega promisla, a tako i iz perspektive Isusova govora. Između Oca i Sina nema tajne. U Isusu se ispunja povijest spasenja: »Sve je meni predao Otac moj i nitko ne pozna Sina doli Otac niti tko pozna Oca doli Sin i onaj kome Sin hoće objaviti.« (r. 27) S tom činjenicom dolazimo do Isusova poziva

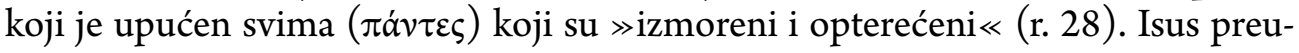
zima na sebe ulogu darovatelja odmora. Ponuda je upućena svima koji prepoznaju svoj umor i opterećenost. Iako se taj poziv ponajprije odnosi na Židove opterećene legalističkim, ljudskim uredbama, ${ }^{37}$ on se tiče i svakoga tko je opterećen ne samo duhovno-religioznim poteškoćama nego i fizičkim poslovima. ${ }^{38}$ Prema tomu Isusov poziv na odmor u kontekstu Post 1, 1-2, 4 upućuje na slavljenje Boga. Samo u Bogu ljudski odmor ima puni smisao jer znači duhovni i tjelesni odmor. Isus je jedini izvor odmora, a ujedno se u njemu proslavlja Bog. Riječ odmoriti (åva $\alpha a v ́ \sigma \omega)$ označava: odmoriti nekoga, obnoviti nekoga. Analiza te riječi upućuje na to da pravi odmor može dati druga osoba, a to je Isus Krist. ${ }^{39}$ Taj se izraz pojavljuje također $\mathrm{u}$ apokaliptičkim tekstovima i povezuje se $\mathrm{s}$ eshatološkom puninom ${ }^{40}$, na što, uo-

\footnotetext{
${ }^{34}$ Usp. H. LANGKAMMER, Evangelia wedtug św. Marka, 122.

${ }^{35}$ Usp. B. T. VIVIANO, Evanđelje po Mateju, u: D. J. HARRINGTON i dr. (ur.) Komentar Evanđelja i Djela apostolskih, 132-225., ovdje 195.

${ }^{36}$ Usp. E. ŠEBA, Free Sunday Campaign, 584.

${ }^{37}$ Usp. R. T. FRANCE, Evanđelje po Mateju, Daruvar, 1997., 208.

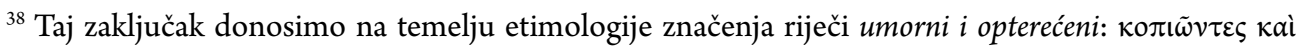
$\pi \varepsilon \varphi \circ \rho \tau \iota \sigma \mu \varepsilon \dot{v}$ ol.

${ }^{39}$ Vidi: Morfološka analiza BibleWorks 6.

${ }^{40}$ Usp. J. HOMERSKI, Ewangelia wg św. Mateusza, Poznań - Warszawa, 1979., 202.
} 
stalom, i skreće pozornost dan Gospodnji. Riječ odmor u Septuaginti poistovjećuje se s hebrejskim šabatom. To povezivanje uvodi u Božji počinak kroz ulazak u Božju mudrost. ${ }^{41}$ To nas upućuje na zaključak da je pravi odmor onaj koji čovjek traži i prima jedino u slavljenju Gospodina u njegovu danu.

\subsection{USKRSNUĆE - DIMENZIJA ŠABATA U NEDJELJI}

Isus je uskrsnuo od mrtvih »prvi dan u tjednu « (Mk 16, 2; Mt 28, 1; Lk 24, 1; Iv 20,1).

$\gg$ Kao dan Kristova uskrsnuća, 'prvi dan', doziva u pamet prvo stvaranje, a kao 'osmi dan', koji slijedi po suboti, označuje novo stvaranje, započeto Kristovim uskrsnućem. Za kršćane je postao prvi među svim danima, blagdan nad blagdanima, dan Gospodnji ('he Kyriake heméra', 'dies dominica'), nedjelja: Sastajemo se u dan sunca jer je to prvi dan kada je Bog, promijenivši tamu i tvar, stvorio svijet. $U$ isti je dan Isus Krist, naš Spasitelj, ustao od mrtvih. $\ll{ }^{42}$

Biblijski tekstovi jednoznačno govore o novoj dimenziji šabata, koja proizlazi iz Isusova uskrsnuća prvoga dana u tjednu i koncizno ga zahvaća.

Mk 16, 1-2

»Kad prođe subota, Marija Magdalena i Marija Jakovljeva i Saloma kupiše miomirisâ da odu pomazati Isusa. I prvoga dana u tjednu, veoma rano, o izlasku sunčevu, dođu na grob. $\ll$

Mt 28, 1

$\gg$ Po suboti, u osvit prvoga dana u tjednu, dođe Marija Magdalena i druga Marija pogledati grob.«

\section{Lk 24, 1}

»Prvoga dana u tjednu, veoma rano, dođoše one na grob s miomirisima što ih pripraviše.«

Iv 20, 1

»Prvog dana u tjednu rano ujutro, još za mraka, dođe Marija Magdalena na grob i opazi da je kamen s groba dignut.«

${ }^{41}$ Usp. G. RAFIŃSKI, Źródło, treść i adresaci objawienia, (Mt 11, 25-30), u: Studia gdańskie 10(1995.), 167-193., ovdje 189.

${ }^{42} \mathrm{KKC}$, br. 2174. 
Kao što se Bog sedmoga dana odmorio od djela stvaranja (Post 2, 2), tako je i Sin Čovječji u grobu počinuo. ${ }^{43}$ Isus prema tomu nije prekršio šabat, nego je u nedjelji otkrio njegov pravi smisao. Nadalje, od toga trenutka nedjelja postaje prvim danom u tjednu, danom kada je Bog stvorio svjetlo (Post 1,3-5), to je početak novoga stvaranja. ${ }^{44} \mathrm{Na}$ nedjeljni dan, nakon subotnjega dana, Gospodin započinje novo stvaranje. ${ }^{45} \mathrm{U}$ nedjeljno jutro ustaje Isus iz groba.

Već u zemaljskom naučavanju Isus je sebi pripisao vlast nad subotom. Duhovna dimenzija njegove ovlasti prekoračuje formalistički rigorizam farizejskih učitelja i pismoznanaca. ${ }^{46}$ Sin Čovječji gospodar je subote $(\mathrm{Mk} 2,28)$. Židovska religijska opozicija zamjerila je Isusu tu tvrdnju. No on, koji je s Ocem jedno (Iv 5, 9) i koji je istina (Iv 14,6), potpuno nasljeduje svoga Oca koji je poslije stvaranja ušao u svoj počinak. ${ }^{47}$ Tako Isusovo uskrsnuće postaje nastavkom Očeva djela stvaranja i prema redoslijedu biblijskoga izvješća o stvaranju nosi sa sobom dimenziju šabata kao središnje točke, usmjerene na Božji uzvišeni počinak.

Duhovni pojam šabata neodvojiv je od sadržaja prvoga dana u tjednu. Subotnji počinak poistovjećuje se s nedjeljnim odmorom i novim vrijednostima koje izviru iz Isusova uskrsnuća. Djelo stvaranja nastavlja se u novom stvaranju prvoga dana u tjednu - u nedjelju. »Krajem I. stoljeća kršćani su počeli svetkovati prvi dan tjedna kao dan Gospodnji, primjenjujući na njega propise obdržavanja šabata (usp. Dj 1, 10 ; 1 Kor 16,2$). \ll^{48}$

\subsection{StVARANJe usmJereno PREMa ŠToVAnJu}

Stvaranje svijeta i obnova svijeta u Isusu Kristu usmjereni su prema šabatu, odnosno prema nedjelji koja je znak novoga saveza u Isusovu pashalnom misteriju. Ratzinger u razmatranju odnosa stvaranja i kulta kaže: »stvaranje je tako ustrojeno da je usmjereno prema času štovanja. Ono se ostvaruje, i uvijek iznova događa, ako ga živimo kao prostor štovanja. Stvaranje je radi štovanja. $\ll{ }^{49}$

\footnotetext{
${ }^{43}$ Usp. A. R. COLE, Evandelje po Marku, 276.

${ }^{44}$ Usp. M. HEALY, The Gospel of Mark, 328.

${ }^{45}$ Usp. C. MITCH, E. SRI, The Gospel of Matthew, Denver, 2010., 365.

${ }^{46}$ Usp. C. SPICQ P. GRELOT, Subota, u: X. LÉON-DUFOUR i dr. (ur.), Rječnik biblijske teologije, 1287-1290. ovdje 1288 .

${ }^{47}$ Usp. isto, 1288-1289.

${ }^{48}$ J. A. SOGGIN, Szabat, u: B. M. METZGER, M. D. COOGAN (ur.), Stownik wiedzy biblijnej, Warszawa, ${ }^{4} 2004 ., 735$.

${ }^{49}$ J. RATZINGER, U početku stvori Bog, Split, 2008., 39.
} 
Pozivajući se na sv. Benedikta, Ratzinger zaključuje da se ništa ne smije pretpostaviti služenju Bogu. Njegova tvrdnja da je ta spoznaja kulturna baština svih religija u čijim se izvještajima o stvaranju govori o tome da svijet postoji radi kulta, radi slavljenja Boga, može biti snažan poticaj za osvješćivanje prvotnoga i izvornoga zahtjeva za traženje neradne nedjelje, a to je kult iz kojega onda sve drugo proizlazi. Nasuprot sekularističkoj kulturi i tehničkoj civilizaciji u kojoj se odbacuje to temeljno znanje, osvješćivanje društva da je štovanje istinsko središte i snaga koja pokreće i uređuje ritam zvijezda i ljudskoga života, koji se pravilno odvija kad je prožet štovanjem, može dati zahtjevu za neradnom nedjeljom izvornu snagu i pravi poredak prioriteta. ${ }^{50}$

\section{Zaključak}

Rad u sedmom danu, šabatu ili u novozavjetnoj nedjelji, strogo je zabranjen u svetopisamskim tekstovima Staroga i Novoga zavjeta, osim u slučaju spašavanja i spasenja. To je dan koji je posvećen Gospodinu i dan odmora. To je dan slobode jer je i rob i slobodnjak, Židov i poganin, domaćin i stranac uživao ista prava slobode od rada; čak su i životinje svojim odmorom sudjelovale u proslavi dana posvećenoga Gospodinu.

Pravo, dužnost i obveza svakoga vjernika jest iskazati štovanje Bogu u taj dan koji je on posvetio, odijelio od svih drugih dana, te on ne može biti kao i svaki drugi dan u tjednu. Oslobođenje iz egipatskoga ropstva izraelskoga naroda započinje zahtjevom za prinošenjem žrtve Gospodinu u pustinji. Pustinja je mjesto slobode, ona je izvan egipatskoga ropstva. Faraon je u strahu da ako im dopusti štovanje pravoga Boga u pustinji da će to značiti njihovo oslobođenje iz ropstva. Pritisnut egipatskim zlima, nastoji s Mojsijem postići politički kompromis oko štovanja u dan subotnji. Mojsije ne pristaje ni na kakve političke dogovore oko štovanja Boga i subotnjega dana, te pred moćnim faraonom ne posustaje u ispunjavanju Božjega zahtjeva; iskazati štovanje Bogu u pustinji. Mojsije ne navodi nikakve druge razloge za odlazak u pustinju na šabat; ni odmor, ni obiteljsko okupljanje, ni težinu ropskoga rada, već jedino i isključivo vjersku dužnost iskazati štovanje Gospodinu prinošenjem žrtve. Samo tada Gospodin svojom moćnom rukom slama otpor vlastodršca koji nema drugoga izbora nego dopustiti nesmetanu religijsku praksu štovanja Boga u subotu u pustinji.

Nakon jasnoga zahtjeva štovanja Boga, koji je prvi i iz kojega proizlaze svi ostali razlozi, Izrael postaje slobodan te se može odmoriti od ropskoga rada kojim ga je pritiskao faraon u Egiptu. Vjerska sloboda štovati pravoga Boga na način i na mjestu

\footnotetext{
${ }^{50}$ Usp. isto, 40.
} 
koji on sam propisuje početak je svih ostalih oslobođenja i sloboda. Društvo koje izgubi religijsku slobodu štovanja pravoga i jedinoga Boga susljedno gubi i ostale slobode i prava jer Gospodin oslobađa i odmara svoj narod u sebi. Zato nas Isus kao Gospodar subote i početak novoga stvaranja u uskrsnom jutru, koje postaje sedmi i prvi dan, oslobađa grijeha i smrti te nas poziva u svoj počinak da nas umorne i opterećene odmori.

Zaključno se može reći da bi svi napori za neradnom nedjeljom trebali započinjati prvim i jasnim zahtjevom prema vlasnicima gospodarskih subjekata i državnim vlastima da smo kao vjernici dužni u nedjelju iskazati štovanje svomu Gospodinu i Spasitelju bez da stavljamo drugotne razloge na prvo mjesto (odmor, obitelj, slobodan dan...), nadajući se da ćemo tako u sekulariziranom društvu naići na razumijevanje za navedene potrebe i tako osigurati i ono na čemu nismo inzistirali kao najvažnijem - bogoštovlje. Ako se to ne dopusti onima koji to traže, jasno i nedvosmisleno, ne pozivajući se prvotno na neke druge razloge za koje misle da će njima privoljeti ili pridobiti moćnike na kompromis, sam Gospodin izborit će se za svoje pravo te omogućiti svojim vjernima da mu iskažu štovanje, uđu u njegov odmor te budu oslobođeni svakoga robovanja u nedjeljni dan.

Odgovor na postavljena pitanja o neuspjehu vjerničkih napora za neradnom nedjeljom, koji se nameće iz biblijske perspektive, sastoji se u nedovoljnom naglašavanju prioriteta štovanja Boga nad svim drugim dobrima koja iz toga proizlaze. Isto tako potrebno je jasnije upozoriti na to da druge slobode proizlaze iz slobode bogoslužja. Povijesni argument imamo u totalitarnim sustavima koji su ugrožavali pravo na javno štovanje Boga koje je dovelo do ugrožavanja ljudske slobode i dostojanstva. 


\title{
WORKING SUNDAY IN CROATIA FROM THE PERSPECTIVE OF THE BIBLICAL SEVENTH DAY
}

\author{
Arkadiusz KRASICKI* - Elvis RAŽOV**
}

Summary: The paper investigates reasons why after the democratic changes in Croatia, despite many activities of civic organizations and the Church itself, there is no work-free Sunday for those professions that are not indispensable for maintaining the regular life of society and the state. The difference between the biblical stencil and current failed attempts is shown from the perspective of believers, through the analysis of biblical texts that speak of the $\gg$ Sabbath $<$ or the seventh day, and the comparison between the experience of the Israeli people coming out of Egyptian captivity, because God demands offering sacrifice in freedom, and the efforts of believers in Croatia today to celebrate Sunday work-free and in freedom. Namely, in the Bible, there is a clear emphasis on the right and duty of believers to first give glory to God, which then allows freedom and rest, while today's attempts, without omitting the former, emphasize the right to rest, family togetherness and the like.

Keywords: Sunday, work-free Sunday, Shabbat, worship of God, freedom, rest.

\footnotetext{
* Asst. Prof. Arkadiusz Krasicki, Ph.D., University of Zadar, Department of Religious Sciences, Ulica dr. Franje Tuđmana 24i, 23000 Zadar, Croatia, akrasicki@unizd.hr

** Asst. Prof. Elvis Ražov, Ph.D., University of Zadar, Department of Religious Sciences, Ulica dr. Franje Tuđmana 24i, 23000 Zadar, Croatia, erazov@unizd.hr
} 